\title{
MORPHO-BATHYMETRY AND GIS-PROCESSED MAPPING IN \\ DELIMITING LACUSTRINE WETLANDS: THE RED LAKE (ROMANIA)
}

DOI: http://dx.doi.org/10.18509/GBP.2015.12

UDC:007:004]:528.94(498)

$551.435 .38(498)$

\section{Prof. Dr. Gheorghe Romanescu \\ Dr. Cristian Stoleriu}

Alexandru Ioan Cuza University of Iasi, Faculty of Geography and Geology, Department of Geography, Bd. Carol I 20A, 700505, Iasi, Romania

\begin{abstract}
The delimiting of wetland boundaries is generally performed by taking into account hydrological, geomorphological, pedological, and biological factors. The hydrogeomorphological factors that are considered include elevation, bathymetry, and the nature of the underlying soil. However, in the case of lacustrine wetlands, two factors affecting the distribution of living organisms have been ignored: the inclination and exposure of the slopes from the photic zone. The wetlands around the Red Lake in Romania were delimited using the maps from sonar bathymetric measurements. The processing of the data using GIS techniques revealed minute details about the features of the slopes and the size of the areas with suitable exposure for the living organisms from the lacustrine cuvette to thrive. The greatest depths $(10.5 \mathrm{~m})$ were observed in the central sector close to the outlet of the two arteries. The cross-section revealed that the western shore was steep and rocky, while the eastern cross-section had a gentler slope and was crumbly due to landslide. The wetlands associated with the Red Lake developed in the sectors with shallow depths, adequate insolation, and organic soils and limnosoils on gentle slopes, which are frequently or permanently inundated.
\end{abstract}

Keywords: GIS, Hydro-geomorphology, Landslide dam, Slope exposure, Slope inclination, Wetland identification.

\section{INTRODUCTION}

The Red Lake is one of the best-known water bodies in Romania. The lake was created as a result of a landslide, which impounded the course of the Bicaz river, like some other lakes in the Carpathians such as the Crucii, Bolatau, Dracului, Iezerul, and Sadovei Lakes. Despite its popularity among tourists, geomorphological studies of the lake have been limited. Although some relevant studies have been made [1-3], most of them are in Romanian or Hungarian, and do not include a modern, interdisciplinary approaches.

A series of measurements was conducted of the morphology of the Red Lake and applied some geomorphological methods to the bathymetry of the lake. An attempt was made to delimit wetlands using GIS (Geographical Information Systems). The depth and slope of the lacustrine basin and the nature of the sediments and the soil type will be determined. From the international literature, only the hydro-geomorphological and ecological studies were used, which helped to understand the functionality of a wetland system [4-12].

\section{GEOGRAPHICAL LOCATION}


The Red Lake is located in the central group of the Eastern Carpathians at the foot of the Hasmasu Mare (Haghimas) Massif (Fig. 1). Its main tributaries are the Oaia, the Verescheu, the Licos and the Suhard streams.

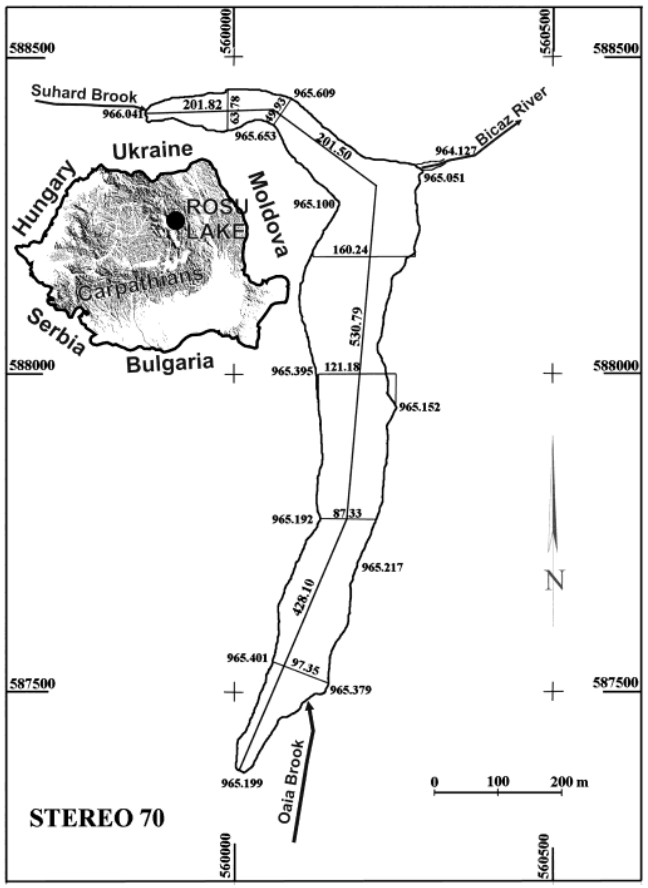

Fig. 1 Geographical location of the Red Lake on the territory of Romania

The Red Lake was created by a landslide in the summer of 1837. After a period of abundant rainfall, a massive slump landslide from the Ghilcos (Ucigasu) impounded the Bicaz stream, leading to the creation of a lake. The tree trunks of the forest that once covered the landslide's body are still visible and protrude from the water's surface.

\section{METHODS AND TECHNIQUES}

The methods employed for this study are traditional in terms of the geomorphologic approach and novel from the biological and limnological points of view. The first consideration was the fact that the lacustrine basin is a scale model of a submerged, inverted mountainous landform; the highest depth corresponds to the peak, while the surface elevation steps correspond to the bathymetric steps. Depending on several cumulative factors specific for each bathymetric step, several habitats can be distinguished. This heterogeneity of the habitats supported the creation of maps modelling the slopes and the slope exposure, as well as the longitudinal and transverse sections of the Red Lake Basin.

The field measurements were obtained using a 1200 Leica system, which includes the LEICA TCR 1201 total station and the LEICA 1200 GPS. The Topographic Headquarters in Gheorgheni provided us with the coordinates of the topographical marks. The measurements were taken starting from Topographic Mark number 15 located on the right side of the lake at an altitude of $986.2 \mathrm{~m}$. The orientation towards the mark on the Suhardului peak was at an altitude of $1,507.0 \mathrm{~m}$. After obtaining the measurements, the data were processed using the AutoCAD Software Suite. 
Simultaneously, a GPS was used to establish the exact perimeter of the lacustrine basin and that of the typical wetlands surrounding the Red Lake. The data of the bathymetric surveys were represented in the Romanian National Stereographic Projection 70 System. The bathymetric measurements were taken using the Valeport Midas Surveyor echo sounder (Bathy-500DF Dual Frequency Hydrographic Echo Sounder). The resolution of this echo sounder is $1 \mathrm{~cm} / 1 \mathrm{~cm}$, and it includes a GPS. The contour of the lake was established on the basis of the topographical measurements and the GPS information. The entire lacustrine surface was measured using sonar.

To process the bathymetric data and create thematic maps, the TNTMips v.7.2 and ArcGis v.9.3 software suites were employed to generate the numerical model of the terrain (DBM; Digital Bathymetric Model). This method constitutes a novel way to produce graphical representations of the mathematical models of lacustrine basins.

The silt samples, which weighed approximately $2 \mathrm{~kg}$, were collected from the surface layer at the bottom of the lake using a sampling scoop. The depth from which the samples were collected varied from 1 to $9.5 \mathrm{~m}$. The total amount of organic carbon was analysed in the laboratory according to the Walkey-Black formula. By multiplying the amount of organic carbon by a factor of 1.724 , the value of the amount of humus in the lake bottom deposits was established. The conventional factor of 1.724, which is based on the assumption that soil organic matter contains $58 \%$ carbon, applies to only specific soils or to particular components of organic matter in the soil. The Romanian System of Taxonomy of Soils (SRTS, 2003) was used as the reference system (conforming to the World Reference Base for Soil Resources, 1998 (WRB-SR)) and was formalised as a single basic reference (1998).

The physical-chemical water parameters were measured using a Hach multiparameter device (manufactured in Germany). The species identification was performed on the basis of the recognition of a surface measuring $10 \times 10 \mathrm{~m}$ [1].

\section{RESULTS AND DISCUSSION}

\section{Morpho-bathymetric parameters}

The topographic measurements indicated the following dimensions: area -12 ha $\left(120,134.4 \mathrm{~m}^{2}\right)$; perimeter $-2,905.7 \mathrm{~m}$; maximum length $-1,361.7 \mathrm{~m}$; maximum width $160.2 \mathrm{~m}$; maximum altitude upstream in the south (the outlet of the Oaia stream) -965.1 $\mathrm{m}$; and maximum altitude upstream in the north-west (the outlet of the Suhard stream) $966.0 \mathrm{~m}$. The length of the main sector (the outlet of the Oaia stream and the river mouth) is $958.8 \mathrm{~m}$. The length of the secondary sector (the outlet of the Suhard stream and the river mouth) is $403.3 \mathrm{~m}$ (Fig. 1). The area that has been determined in recent studies is $11.6 \mathrm{ha}$, or $116,500 \mathrm{~m}^{2}$.

The lowest depths are recorded in the upstream sectors of the two branches at the outlet of the two most important streams: the Oaia and the Suhard. This fact is a result of the relatively lower transport rate of solids from the two watercourses. The diminished discharge of solid alluvium is the result of a dense forest cover that has existed there since the formation of the lake. Lower depths were also recorded near the mouths of the small torrents originating from the steep mountain sectors.

The greatest depth $(10.5 \mathrm{~m})$ was recorded in the central sector at the confluence of the two main inflows behind the landslide dam. The greater difference between the levels of the Suhard stream and the river mouth led to the appearance of greater depths along this profile compared to the depths located between the Oaia stream and the outlet. Until 
recently, only maximum depths of $9.7 \mathrm{~m}$ had been measured. The measurements recorded in the summer of 2009 indicated values of approximately $10.5 \mathrm{~m}$. Only one study showed a depth of $10.5 \mathrm{~m}$. It is important to mention that these measurements were recorded during a long time interval during which record high levels of precipitation occurred. This phenomenon resulted in a slight increase in the water levels but did not exceed $20-30 \mathrm{~cm}$.

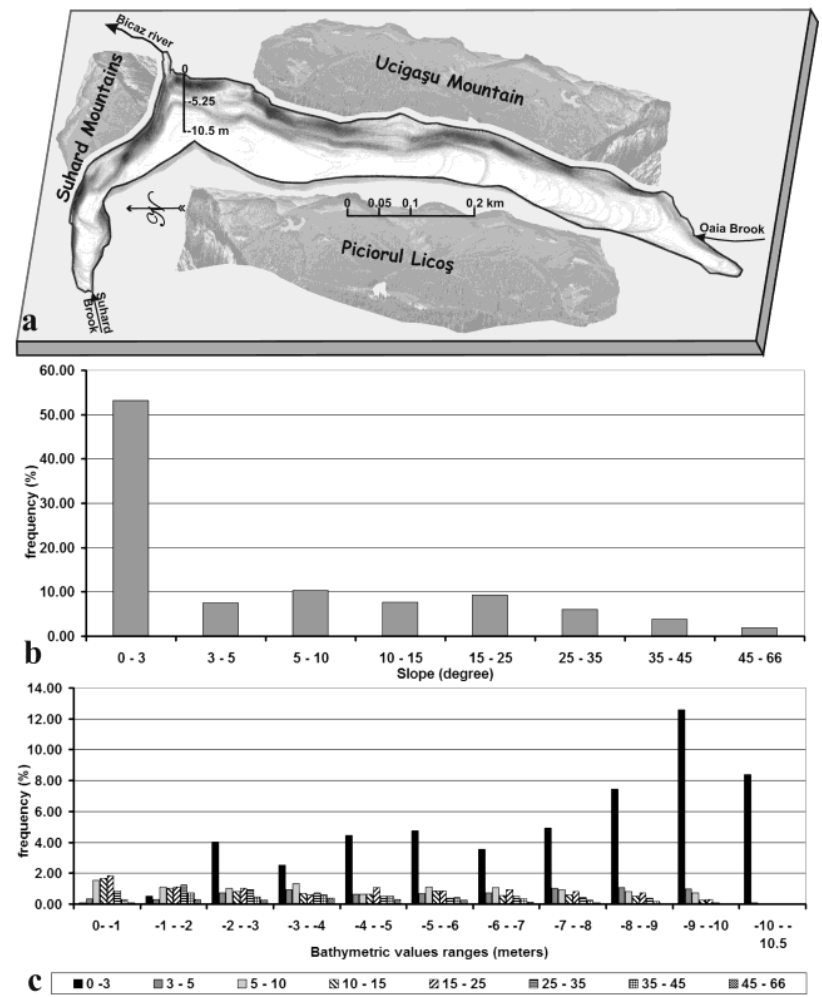

Fig. 2 3D model of the Red Lake Basin (a); The average distribution (\%) of the slopes in the Red Lake Basin (b); Distribution (\%) of the slopes for each depth interval (c)

In a transverse profile, a clear asymmetry of the slopes can be observed. In the remote sector towards the Ghilcos Mountain where the sliding material was detached, the slope becomes gentler, whereas the opposite slope is very steep. The greatest relief is recorded in the sector of the river mouth where the greatest depths are found (Fig. 2a). Perfect symmetry was recorded in the upstream sectors where silting is predominant and the quantity of erosive material is low.

The steepest inclinations were found on the western and northern shores, where the rocky slopes that rise almost vertically above the lacustrine basin are well forested. These areas are not a source for any significant watercourses, and the quantity of alluvial material is low. In the areas with reduced depths where light penetrates to the bottom of the lake, a vegetation type specific to extensive wetlands has developed. The vegetation significantly contributes to rapid silting in the upstream sectors of the two branches. Simultaneously, the vegetation created a soil typical of the lacustrine basins called limnisoil [6, 9].

The water level in the lake is between $965 \mathrm{~m}$ and $966 \mathrm{~m}$. Therefore, the morphometric maps must be updated because the maps that were expanded from 1950 to 1970 contain many errors. Slopes with inclinations ranging from $0-3^{\circ}$ are the most common (over $50 \%$ ), and the lowest occurrence values are found for slopes with inclinations ranging from $45-66^{\circ}$ (less than 2\%) (Fig. 2b). A remarkable percentage (almost 10\%) of slopes have an inclination from $5-10^{\circ}$ or $15-25^{\circ}$. 

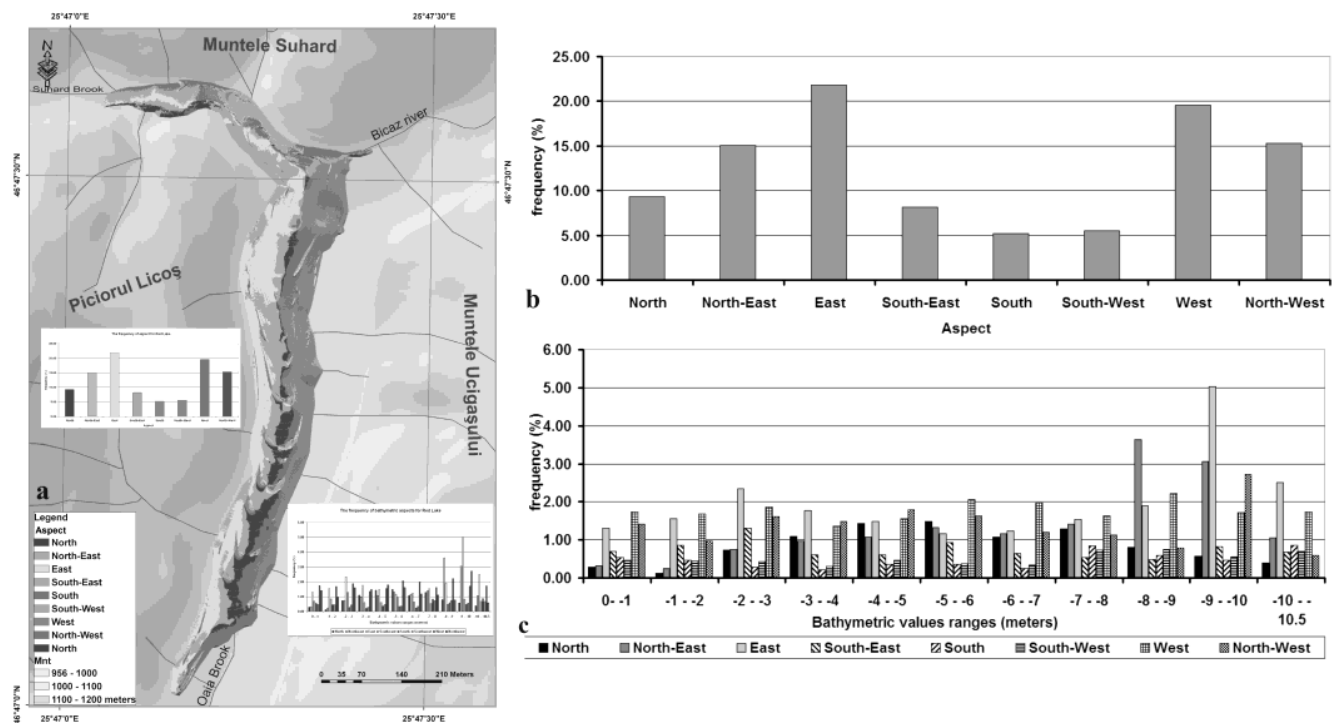

Fig. 3 Map of the orientation of the banks (slope orientation) in the Red Lake lacustrine basin (a); Average distribution (\%) of the orientation of the submerged banks (slopes) in the Red Lake Basin (b);

Distribution (\%) of the orientation of the submerged banks (slopes) for each depth interval (c)

At lower depths $(0-1 \mathrm{~m}, 1-2 \mathrm{~m})$, the average slopes are predominant, while at greater depths (particularly for the depths between 8-9 m, 9-10 m, and over $10 \mathrm{~m}$ ), the gentler slopes are predominant (Fig. 2c). For depths exceeding $9 \mathrm{~m}$, slopes with values between $0^{\circ}$ and $3^{\circ}$ are predominant. Therefore, the lake bottom is uniform. An important ecological characteristic of the lacustrine basins is supported by the slope's orientation and the slope's exposure (Fig. 3a). The aspect of the shore face relative to the sun controls the distribution of the lacustrine organisms. The highest values are characteristic of the shores with eastern, north-eastern and north-western exposures (Fig. 3b) along the axis of the lake. The lowest values are characteristic of the southern and south-western banks. There are important differences in the exposure of the shores at different depths. The general phenomenon somehow changes in the middle part of the lake, between the depths of 4-5 m, 5-6 m, and 6-7 m, where other exposures are predominant (Fig. 3c). At greater depths, the eastern and north-eastern exposures are predominant. This finding can be attributed to the inclination of the submerged glacis formed on the bedrock slope.

In a longitudinal profile, the relatively high bluff in the sector between the Oaia stream and the river mouth $(10.5 \mathrm{~m}$ at $958.8 \mathrm{~m})$ can be observed. The slope of the sector between the Suhard stream and the river mouth has a value of $10.5 \mathrm{~m}$ at $403.32 \mathrm{~m}$. In the latter case, the slope is significantly steeper; therefore, great depths are maintained for the entire course. The general slope of the water level between the Oaia stream and the river mouth profile has a value of $0.015 \%$, and the slope of the lake bottom has a value of $1.1 \%$. In contrast, for the sector between the Suhard stream and the river mouth, the slope of the water level has a value of $0.24 \%$, and the slope of the lake bottom is $2.8 \%$. The landslide body impounding the basin of the Red Lake has a slope with well-defined vertical values and little time-varying change. It is precisely this stability that has maintained the water levels and ensured the existence of the lake. 

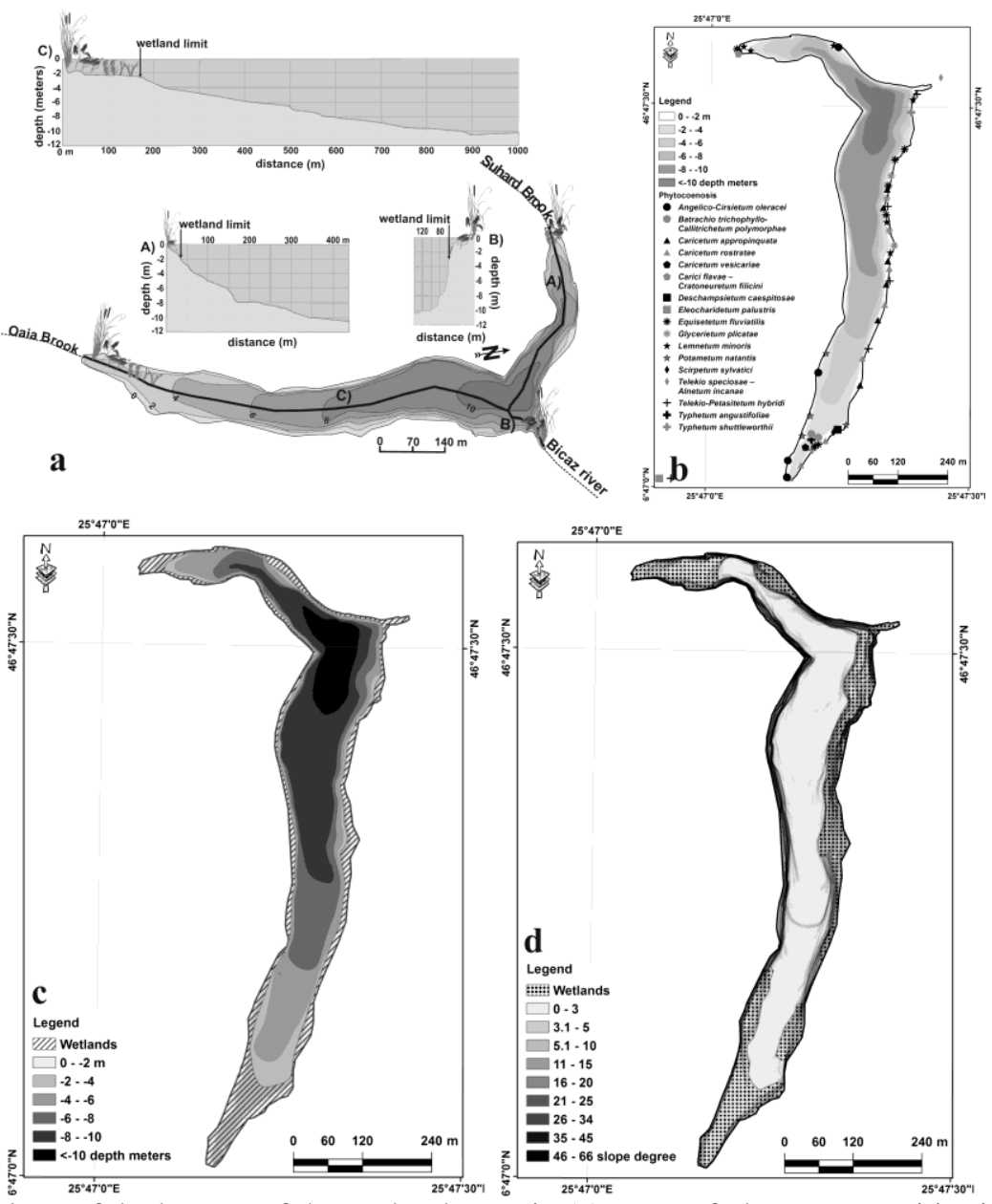

Fig. 4 General slope of the bottom of the Red Lake Basin (a); Map of plant communities in the Red Lake area (b); Bathymetric map of the Red Lake and the delimitation of the lacustrine wetland extending to a depth of $3 \mathrm{~m}$ (photic layer) (c); Lacustrine wetlands delimitation according to the value of the submerged slopes (d)

The greatest depths of $10.5 \mathrm{~m}$ can be found at the confluence of the two inflows, the Oaia and the Suhard, behind the body enclosing the lacustrine basin (Fig. 4a,b). The significant depths in this sector could be explained by the currents from the circulation of the lake's bottom. These currents can be generated when the longitudinal currents reverse after hitting the dam. In this case, under-washing at the bottom of the riverbed occurs, and deep pools are created. The vertical distribution of the depths creates a transversal profile of the lacustrine basin in a conical shape. The area within the isobath $(1 \mathrm{~m})$ is $11.2 \mathrm{ha}$, and the area within $10 \mathrm{~m}$ is only 0.056 ha. At the level of each bathymetric curve, an equivalent solar energy is received. The amount of solar energy varies, depending on the turbidity, the transparency, the degree of vegetation and the ice sheet cover (i.e., isolated or continuous).

The general slope of the lake bottom profile is $11^{\circ}$ from the Oaia stream to the river mouth, $26^{\circ}$ between the Suhard stream and the river mouth, and $56^{\circ}$ along the profile of the confluence between the two sectors and the main spillway (Fig. 4a,b). The decreased slope in the southern sector can also be explained by its greater length. The steeper slope of the northern sector is a result of its reduced length. The steep slope near the river mouth is a result of the presence of the landslide body. 
For each bathymetric interval $(0-1 \mathrm{~m} ; 1-2 \mathrm{~m}$, etc.), there is a corresponding equivalent water volume $(\mathrm{Vp})$ with specific physic-chemical and biological characteristics. Certain ecological functions can be assessed accordingly. For each interval, there is a corresponding value for the submerged surfaces of the landforms affected by exogenous factors.

\section{Wetland delimitation}

In the category of wetlands and habitats with deep waters, the following systems can be distinguished: riverine, palustrine, lacustrine, deltaic, estuarine and marine. Two types of systems are characteristic of the Red Lake: palustrine (with temporary flooding) and lacustrine (with permanent flooding). In the area of the palustrine marshes, the soil humidity is permanent, even during the summertime. The relatively low thermal values result in a low level of evaporation. An influence of salinity is not observed.

The slope of the Suhard stream is considerably large, and the bottom of the valley is deep. The smaller distance indicates a greater difference in these levels. The Oaia stream and the associated lacustrine sector have a greater length but a smaller slope. In this case, the sedimentation rate may be higher because the current has a lower velocity and the removal of the deposits is slower. The shallowest depths are recorded in the upstream sectors of the two branches at the outlet of the most important streams, the Oaia and the Suhard. This fact is a result of the relatively low quantity of solid alluvia that is transported by the two watercourses. The reduced solid discharge is, in turn, due to a dense forest cover that has been maintained since the initial formation of the lake. Reduced depths are also recorded next to the river mouths of the small torrents originating from the mountain sectors with high slopes (Fig. 4c).

In the cross-section view, a clear asymmetry of the slopes can be observed. In the remote sector towards the Ghilcos Mountain from where the sliding material was detached, the slope becomes gentler (C), while the opposite rocky slope is very steep (A). The highest relative relief is recorded in the sector of the river mouth (B) with the greatest depths (Fig. $4 a, b)$. A perfect symmetry is observed in the upstream sectors, where the silting is predominant and the quantity of the sliding material is reduced (Fig. 4d).

The highest slopes are found on the western and northern shores, where the rocky slopes have an almost vertical drop into the lacustrine basin. These sectors are well forested, they are not the source of any significant watercourses and the quantity of alluvia material is low. A different situation occurs on the opposite eastern slope, where the landslide diluvium has manifested. In this case, the slopes have low values; thus, a plant community is able to develop. This latter sector is strongly traversed by several sporadic torrential streams. The streams are presently anthropically controlled because this area is passed by a road linking Bicaz and Gheorgheni.

The delimitation of the wetlands is performed by taking into consideration hydrological, geomorphological, pedological, and biological criteria. For the geomorphological delimitation, bathymetric and slope maps are used. In addition to the basic conditions, the physical-chemical parameters of the water are considered.

The delimitation of a submerged wetland (palustrine) with reduced depths is simple. The submerged wetland should be a maximum of 2-3 $\mathrm{m}$ deep or, in the present case, to the photic layer with its productive bottom ( $3 \mathrm{~m}$ deep). The maximum transparency of the Red Lake is $3 \mathrm{~m}$. Minimal transparency occurs during heavy rains when the streams transport large amounts of alluvium, at which point the transparency decreases to 10-15 $\mathrm{cm}$. Maximum transparency occurs in the central, and deepest, sector. From this point of 
view, three important areas with wetlands of ecological importance are delimited: the mouth of the Oaia stream, the mouth of the Suhard stream and the main river mouth (Fig. $4 \mathrm{~b})$. The accompanying wetlands are almost continuous along the shores of the lake (except for the rocky slopes, which drop directly into the lake) and have variable sizes. The delimitation based on the slope is relatively similar to the delimitation based on the bathymetry, but a greater extension of the wetland associated with the landslide body with less steep slopes can also be observed. In the case of the western or northern rocky slopes, the wetlands are of narrow width or are absent. The thickness of the lacustrine sediment layers varies significantly, reaching a maximum of over $6 \mathrm{~m}$ in the spillway sectors of the two major streams, the Oaia and the Suhard.

The typical soils for the wetlands are hydric soils for the emerged sectors and limnosoils for the submerged sectors. For the delimitation of the submerged wetlands, the total organic carbon content and the humus content are considered. A clear connection can be observed between the total organic carbon content and the humus content. At shallow depths, higher amounts of organic carbon and humus are present; at greater depths, the finest deposits are found with the most reduced amounts of organic carbon and humus. The more reduced the slope angles and depths are, the higher the concentrations of organic carbon and humus are. In the deepest sectors, especially towards the lake's outlet, smaller quantities of organic material are found.

The highest organic carbon contents are $7.31 \%$ at the spillway of the Oaia stream and $6.10 \%$ at the spillway of the Suhard stream. The lowest value $(3.73 \%)$ is recorded near the river mouth, where the greatest depths are also found. The high values of humus are due to the rich vegetation in the shallow sectors, where the water column is thoroughly illuminated and the roots of the plants can penetrate the soft layer. These are the most important wetlands around the lake. The hummus in the lake sediments that forms the specific limnosoils develops from two sources: the soil eroded from the slopes and decomposed plant material. The highest values of humus are 12.7 at the spillway of the Oaia stream and 10.53 at the spillway of the Suhard stream. The lowest value, 6.43, is recorded at the river mouth with the greatest depth.

The existence of a significant amount of humus and a typical limnisoil implicitly facilitated the development of immersed and submerged vegetation. This fact is typical for depths up to 2-3 m. For greater depths, light hardly penetrates the water; therefore, the bottom of the lake lacks such life forms. This area is the domain of the bacteria and animals that are resistant to extreme conditions involving oxygenation, $\mathrm{pH}$, salinity, and pressure. The lowest quantities of organic carbon and humus are found on the steeper rocky slopes (the western and northern slopes), where the depths of the lake are also greater. This is due to the weak erosion of the slopes (due to a dense forest cover) and the absence of water streams (resulting in a reduced sediment supply). The physical-chemical properties of the lake's water are not significantly different from those of the streams that supply it. There are minor chemical differences in the water originating from the various main tributary streams. Considering the physical-geographical factors mentioned above, the plants create specific associations in the lake and on its shores (Fig. 5).

The arborescent species are common for all of the wetlands: Populus alba, Alnus glutinosa, and, with a lower frequency, Salix alba [1]. Considering all of these conditions and using the aerial images (ortophotos), an exact delimitation of the most important immersed and submersed wetlands in the three sectors was carried out (Fig. 6). In this study, only the wetlands with ecological importance were chosen because they are weakly modified by human interference. The delimited surfaces cover an area of 4.0 ha at the 
mouth of the Oaia stream, 0.3 ha at the river mouth and 0.1 ha at the mouth of the Suhard stream. The total area of the wetlands that were considered to be of great ecological importance is 4.5 ha.
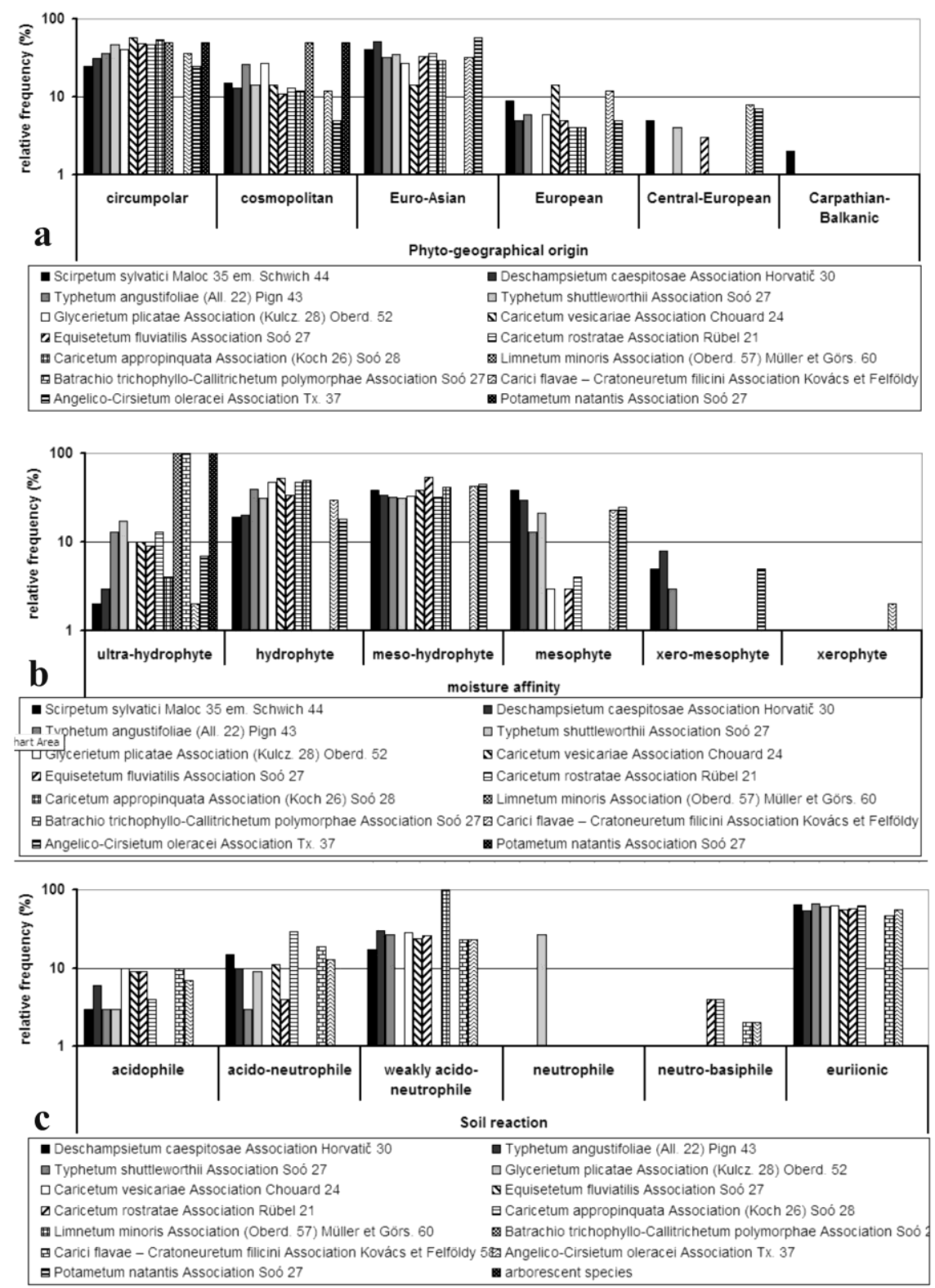

Fig. 5 Relative frequency of plants with respect to their phyto-geographical origins (a); Relative frequency of plants with respect to the moisture affinity (b); Relative frequency of plants with respect to the soil reaction (c)

Recent housing developments and the onset of minimal deforestation have caused significant siltation and a slight eutrophication of the water. The issue is not severe, but a warning should be issued to preserve the clean water and the optimum conditions in the wetlands.

\section{CONCLUSIONS}

The use of new survey data and GIS applications using the slope inclination and exposure maps has enabled a more detailed and accurate delimitation of the wetlands from this 
ecosystem. For future limnological studies, particularly for those that investigate the nature and role of the environmental factors, it is necessary to use these two parameters in ascertaining the local conditions.

The Red Lake is the best-known landslide-dammed lake in Romania, and, together with the Bicaz Gorges, it is one of the main tourist attractions in the area of the Hasmasu Mare (Haghimas) Mountains. Aspects of the geomorphologic, hydrological, and ecological landscape, as well as tourism factors, will cause radical changes in the neighbouring environment and will have an important impact on the lacustrine basin unless an adequate management programme is implemented.

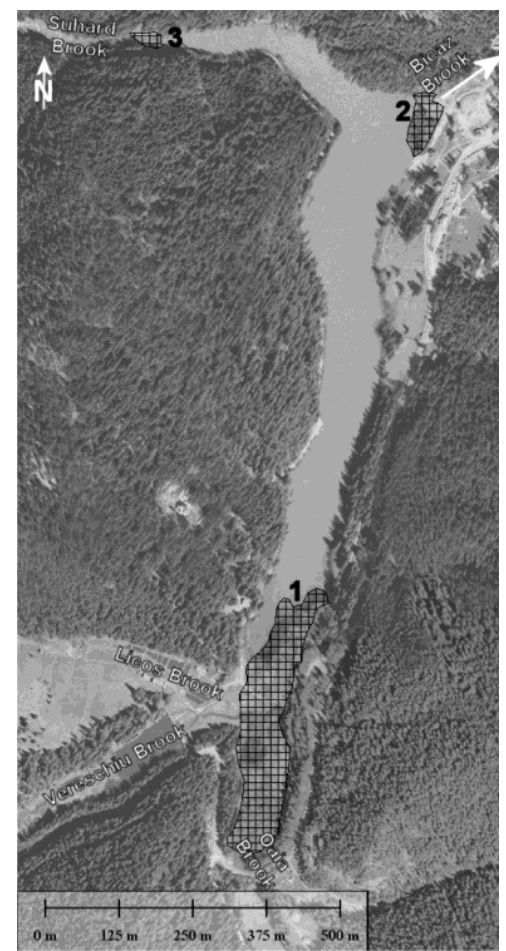

Fig. 6 Delimitation of the compact wetlands of great ecological importance (lacustrine and palustrine)

Although the lake is a distinct entity from a limnologic point of view, most of the studies were of a limited character, and an interdisciplinary approach was not adopted. The only study with an integrating character was published by Pandi in 2004. Due to a less accurate methodology and outdated instruments, even this study includes inaccurate data from a morphometric point of view (e.g., topography, bathymetry).

The morphological elements of the lake basin are different on each of the two main banks. On the rocky bank, the slopes are high, while on the bank affected by landslides, the slopes are reduced. These factors have favoured the appearance of vegetation on the bank occupied by landslide materials and the absence of vegetation on the rocky bank.

Favourable sedimentary parameters and a balanced inflow-outflow discharge pattern have worked together to ensure the existence of the lake over the last 150 years. The low degree of silting-up is the result of the high degree of forestation in the hydrographical basin and of the existence of hard rocks that are resistant to erosion. If the development of summer homes continues at the same pace in the future, the trend will inevitably lead to the deforestation of the entire surrounding area and, therefore, to accelerated erosion. The existence of wetlands around the mountain lakes is more restricted because of the reduced amount of surfaces that are suitable for plant growth compared to the wetlands 
in plain or hilly areas. To preserve the wetlands and the hydrological equilibrium in the Red Lake Basin, measures of the hydrological management of both the main and secondary watercourses have been recorded. The most necessary measures concern the control of the water inflow and outflow, the sediment influx from the basin, and, finally, the management of floods.

\section{ACKNOWLEDGMENTS}

This study was supported by a Marie Curie International Research Staff Exchange Scheme Fellowship within the $7^{\text {th }}$ European Community Framework Programme (PIRSES-GA-2012-318969).

\section{REFERENCES}

[1] Nechita N. The flora and vegetation of the cormophytes from Hasmas Massif, Bicaz Gorges and Lake Rosu. Bibliotheca Historiae Naturalis II, Natural Sciences Museum, Piatra Neamt (in Romanian), 2003.

[2] Romanescu G., Stoleriu C. \& Enea A. Limnology of the Red Lake, Romania. An Interdisciplinary Study. Springer, Doldrecht, 2012.

[3] Romanescu G., Stoleriu C. \& Lupascu A. Biogeochemistry of wetlands in barrage Lacul Rosu catchment (Haghimas - Eastern Carpathian). Environmental Engineering and Management Journal, 11(9), pp.1627-1637, 2012b.

[4] Mihu-Pintilie A., Romanescu G. \& Stoleriu C. The seasonal changes of the temperature, $\mathrm{pH}$ and dissolved oxygen in the Cuejdel Lake, Romania. Carpathian Journal of Earth and Environmental Sciences, 9(2), pp. 113-123, 2014.

[5] Nolan M. \& Brigham-Grettej J. Basic hydrology, limnology, and meteorology of modern Lake El'gygytgyn, Siberia. Journal of Paleolimnology, 37(1), pp. 17-35, 2007.

[6] Romanescu G., Dinu C., Radu A. \& Torok L. Ecologic characteriyation of the fluviatile limans in the south-west Dobrudja and their economic implications (Romania). Carpathian Journal of Earth and Environmental Sciences, 5(2), pp. 25-38, 2010.

[7] Romanescu G., Sandu I., Stoleriu C. \& Sandu I.G. Water Resources in Romania and Their Quality in the Main Lacustrine Basins. Rev. Chim. (Bucharest), 63(3), pp. 344-349, 2014.

[8] Romanescu G., Tarnovan A., Sandu I.G., Cojoc G.M., Dascalita D. \& Sandu I. The Quality of Surface Waters in the Suha Hydrographic Basin (Oriental Carpathian Mountains). Rev. Chim. (Bucharest), 65(10), pp. 1168-1171, 2014.

[9] Romanescu G. \& Cojocaru I. Hydrogeological considerations on the western sector of the Danube Delta - a case study for the Caraorman and Saraturile fluvial-marine levees (with similarities for the Letea levee). Environmental Engineering and Management Journal, 9(6), pp. 795-806, 2010.

[10] Romanescu G. \& Stoleriu C. Seasonal Variation of Temperature, pH and Dissolved Oxygen Concentration in Lake Rosu, Romania. CLEAN - Soil, Air, Water, 42(3), pp. 236-242, 2013.

[11] Wentworth T.R., Johnson G.P. \& Kologiski R.L. Designation of wetlands by weighted averages of vegetation data: A preliminary evaluation. Water Resources Bulletin,. 24, pp. 389-396, 1988.

[12] Ying J.F., Xin Ch. \& Cheng L.A. A Comparative Study on the Growth and Nutrient Uptake Charasteristics of Fifteen Wetland Species in Taihu Lake Region of China. International Journal of Environmental Research, 5(2), pp. 361-370, 2011. 
International Scientific Conference GEOBALCANICA 2015 